\section{The effects of partially replacing cement by glass waste powder on concrete properties}

Antonio BOUTY - City University, POB. 676, Muhieddine Makkouk Boulevard, Tripoli, Lebanon - Antonio.bouty@outlook.com

FARAh HOMSI - ESIB, Université Saint-Joseph De Beirut Mar Roukos, POB. 11-154, Riad El Solh, Beyrouth, Lebanon • farah.homsi@usj.edu.lb

Érkezett: 2020. 07. 21. - Received: 21. 07. 2021. - https://doi.org/10.14382/epitoanyag-jsbcm.2021.7

\begin{abstract}
The cement production causes different types of pollution in addition to the high amount of energy needed for the manufacturing process, starting by the site extraction and ending by the factory production; at the same time millions of tons of glass waste are dumped yearly at landfills. This research verifies the possibility of partially replacing cement by glass waste powder (GWP) in new concrete mixes. For this purpose, two different concrete mixes having compressive strengths of $25 \mathrm{MPa}$ and $32 \mathrm{MPa}$ were made with 0\%, 10\%, 15\%, 20\% and 25\% of GWP as a partial replacement of cement. The properties of fresh concrete mixes were determined by the slump, air content and flow table tests. Concerning the tests on hardened concrete, the compressive strength test was carried out on cylindrical specimens at 7,14 and 28 days in addition to the water absorption and the tensile strength tests at 28 days. As a result, the partial replacement of cement by GWP showed no clear effect on the properties of the fresh concrete mixes. Whereas, $10 \%$ GWP in $25 \mathrm{MPa}$ concrete mix gave higher compressive and tensile strengths at 28 days and increased the moisture content; and 15\% GWP in $32 \mathrm{MPa}$ concrete mix gave the higher compressive strength at 28 days but decreased the tensile strength and the moisture content. Keywords: recycled glass, environment, compressive strength, fresh concrete properties, cement production, sustainability

Kulcsszavak: újrahasznosított üveg, környezet, nyomószilárdság, friss beton tulajdonságok, cementgyártás, fenntarthatóság
\end{abstract}

\section{Introduction}

Lebanon suffers from specific and deep-rooted problems affecting waste collection, waste treatment and disposal of municipal solid waste. Since 1997, the waste sector in Lebanon has operated under an emergency municipal solid waste management plan, which ended in July 2015 . This culmination in the current national trash crisis was mainly triggered by the premature closure of Lebanon's largest sanitary landfill located in Naameh in July 2015. These problems have led to significant social, economic, and environmental difficulties. In Lebanon, open dumping, and open burning of municipal waste is a common and widely accepted practice. As the case of Lebanon, most of the developing countries are facing shortage of post consumer's disposal waste sites that is becoming a very serious problem. For this reason, regenerating and using waste products as resources is necessary to prevent environmental pollution. According to GMI (Green Med Initiative), Lebanon produces around 2.04 million tons of municipal solid waste per year and glass represents $3.5 \%$ of this amount [1].

In Lebanon, the cement industry is the largest source of carbon dioxide emission; in addition, cement factories are also responsible for the emission of Nitrogen Oxide, Sulfur Monoxide, and Carbon Monoxide in the atmosphere. High concentrations of these pollutants in the atmosphere have detrimental effects on the human body and also cause environmental problems such as ozone depletion, water quality deterioration and acid rain [2].
Farah HOMSI

was born in 1984, she received a diploma in Civil Engineering from the Lebanese University in 2007, a Master's degree in Geological, Civi and Environmental Engineering from Bordeaux 1 University in 2008 and a Ph.D. degree in civi Engineering from Ecole Centrale de Nantes in 2011. From September 2019, she is a Full-time Assistant Professor at the department of Civil and Environmental Engineering at the Higher School of Engineering at Saint Joseph's University, teaching Construction Materials, General Construction Procedures, Traffic Engineering, Road and Pavement Engineering. Between February 2017 and August 2019, she was an Assistant Professor at the Civil Engineering Department at City University and the Lebanese American University. From September 2012 till January 2017, she was a Full-time Assistant Professor at the Department of Civil and Environmental Engineering in Beirut Arab University, teaching Transportation Planning and Traffic Engineering, Highway Engineering, Elementary Structural Analysis, Construction

Materials and Mechanics of Materials. She was also the Coordinator of the Civil and Environmental Engineering Department, and the Academic Coordinator of the Faculty of Engineering. From September 2011 to August 2012, she was a Full-time Assistant Professor at the Department of Civil and Environmental Engineering in Mechanics and Engineering Institute (I2M), Bordeaux I University in France, teaching Pavement Design, Computer Aided

Design, Soil mechanics and Construction Materials. She received the Young Researchers' prize: René Houpert, from the French Academic Association of Civil Engineering (AUGC), in 2011. was born in 1995, he received a Master's degree in Civil and Environmental Engineering from City University in 2019. From March 2020, he is enrolling in the master's program of Building's Retrofitting at the department of Civil Engineering at Università degli Study di Genova (Genova, Italy).Between October 2019, and February 2020, he was a Part-time University Instructor at the department of Civil and Environmental Engineering at City University, teaching Construction Materials, and examining graduating students' projects.

One of the possible solutions that might minimize the environmental impacts of cement production and glass waste dumped at landfills, is to partially replace cement by glass waste powder in new concrete mixtures. On the one hand, it helps reducing the toxic gases resulting from the manufacturing process of cement and on the other hand, it valorizes glass waste instead of being dumped in landfills. Since glass is mainly composed of silica, when it is milled down into micro size particles, it is expected to undergo pozzolanic reactions with cement hydrates, forming secondary Calcium Silicate Hydrate (C-S-H) that provide strength for the concrete mix.

To study the mechanical properties of concrete when neon glass, brown glass, and green glass partially replace cement, [3] chose a design compressive strength of $35 \mathrm{MPa}$ to be achieved at 28 days, with three different replacement ratios of cement by each type of glass $(11 \%, 13 \%$ and $15 \%)$. Their results have pointed out that the compressive strength increases proportionally with curing process because the hydration process is continuous until getting the full strength of concrete; the highest compressive strength that appeared at 28 days was 
31.75 MPa with $13 \%$ replacement of cement by neon glass. The results of splitting tensile strength tests showed that the splitting tensile strengths of the three different types of glass were greater than that of the control concrete mix, especially for green glass where the higher value was recorded at $13 \%$ replacement. The results also showed that the splitting tensile strength increased gradually at $11 \%$ and $13 \%$ for neon, green, and brown glass but decreased at $15 \%$ for all the three types of glass.

[4] tested four different replacement ratios of cement by glass waste powder $(5 \%, 10 \%, 15 \%, 20 \%$ and $25 \%)$ in order to achieve a target compressive strength of $35 \mathrm{MPa}$. The difference in compressive strengths between the control mix and the mix with $25 \%$ glass replacing cement at 180 and 365 days were further reduced and provided similar mean compressive strengths. At the age of 180 and 365 days, the $20 \%$ replacement of cement by glass gave $10 \%$ and $14 \%$ respectively higher strengths than the control concrete mix. The results revealed that an increase in the replacement ratio of glass resulted in a slight increase in the mortar flow while a minor effect on concrete workability was noted. In addition, the results have shown that the compressive strength was decreasing with the addition of glass powder in recycled glass mortar and concrete, but gave better strength compared to control samples at later age.

[5] took the waste bear bottles and soda lime glass and transformed them into powder of $75 \mu \mathrm{m}$ diameter to study the pozzolanic reaction of glass powder for up to $60 \%$ cement replacement and its influence on the microstructure of cement paste, which has not been investigated before. The design compressive strength in this study was $48 \mathrm{MPa}$ and four percentages of cement were replaced by glass waste powder (15\%, 30\%, 45\% and $60 \%$ by weight of cement). As a result, the rate and the total heat generated during the hydration consistently decreased with higher glass powder content due to the dilution of cement in the mix. Concerning the compressive strength at 28 days, the $30 \%$ replacement of cement by glass waste powder gave $49 \mathrm{MPa}$ (the highest compressive strength), whereas its compressive strength was $55 \mathrm{MPa}$ at 91 days. The results have revealed that this increase in later age strength was not observed for concrete in which more than $30 \%$ cement is replaced by glass waste powder. Therefore, there is an upper limit for cement replacement level, beyond which no further pozzolanic reaction of Glass Waste Powder (GWP) can occur; this replacement level is lower than $30 \%$.

[6] has summarized in her research entitled "Performance of lamp glass waste powder (LGWP) as supplementary cementitious material (SCM) - viscosity and electrical conductivity" the experimental results of a laboratory test series carried out on cement mortar specimens, in which two different lamp glass waste powders were used as cement component: the incandescent light bulb borosilicate glass waste cullet powder (LGWP1) and the fluorescent lamp tube glass waste cullet powder (LGWP2). Patricia had demonstrated that Portland cement substitution with lamp glass waste powders at a level of $30 \%$ is possible without any strength loss, moreover, the addition of superplasticizer admixture led to an increase in compressive strength by $15-17 \%$ in comparison to the control mortars.

[7] substituted the cement with waste glass powder at levels of $20 \%$ or $30 \%$ per mass. It was demonstrated that the waste glass powder addition improves the workability of fresh pastes and can be effectively used as cement replacement for compressive strength. It was also demonstrated that the particle size of the waste glass powder (specific surface area) has a stronger influence on the effectiveness of the cement replacement than the chemical composition. The effectiveness of the cement replacement increases as the specific surface area increases.

The results in the literature review showed promising results in terms of the effect of partial replacing the cement by glass waste powder in new concrete mixes and motivated the researchers to undergo an experimental study to analyze the GWP generated in Lebanon and evaluate its effects on the fresh and hardened properties of concrete.

\section{Experimental plan}

In this study, two different concrete mixes having compressive strengths of $25 \mathrm{MPa}$ and $32 \mathrm{MPa}$ were performed with different replacement ratios of cement by glass waste powder, with reference to the absolute volume method [8]. These two compressive strengths were taken in order to try if possible to not limit our uses only by the $25 \mathrm{MPa}$ concrete mix in all the structural elements of a real life project, especially in high-rise buildings where there is a need to increase the compressive strength of some beams and columns in some stories instead of enlarging there sections, which the architect might not agree on. The different percentages of cement that were replaced by the glass waste powder were the following: $0 \%, 10 \%, 15 \%, 20 \%$ and $25 \%$. This resulted in 10 different concrete mixes that were prepared and tested in the laboratory. The maximum replacement ratio was limited by $25 \%$ due to the crushing method of the glass that takes a lot of time to give the wanted particles size.

The tests conducted on fresh concrete included the slump test, flow table test, and the air content test. Concerning the hardened concrete tests, the compressive strength test was performed to obtain the compressive strength; the concrete specimens were crushed at 7, 14 and 28 days with three specimens at each age; therefore, nine specimens were tested for the compressive strength [9], and one additional specimen was tested for the indirect tensile strength test [10]. In total 50 cylinders of $150 \mathrm{~mm}$ diameter and $300 \mathrm{~mm}$ height were prepared for each concrete mix. Furthermore, the water absorption test was conducted to evaluate the effect of inclusion of glass powder on the porosity of concrete [11].

\section{Materials}

\subsection{Cement}

The ordinary Portland cement used is fabricated by Holcim (Liban) S.A.L, according to the Lebanese specifications LIBNOR (NL 53:1999) for the cement PA-L, 42.5. The specific gravity and the density were found to be 3.15 and $1551 \mathrm{~kg} / \mathrm{m}^{3}$ respectively [8]. 


\subsection{Glass}

The chemical analysis by Energy Dispersive X- Ray Fluorescence Spectrometer (ARL-9800 XP) of the glass waste powder and Portland cement showed in Fig. 1, indicates that the waste glass collected from Golden Glass Company located at Al-Badawi / North Lebanon, has a high percentage of silica and has almost the same content of ordinary Portland cement but with different percentages. The glass was crushed using the Los Angeles machine in order to minimize the particles size to less than $75 \mu \mathrm{m}$ (see Fig. 2). Crushing $8 \mathrm{~kg}$ of glass waste into the Los Angeles machine took six hours and resulted in approximately $3 \mathrm{~kg}$ of glass powder of less than $75 \mu \mathrm{m}$ particles size.

The density of the GWP was determined to be $1200 \mathrm{~kg} / \mathrm{m}^{3}$, by dividing the mass of the glass powder filled in a cylinder by its volume; in addition, using the Chatelier apparatus, the specific gravity of the GWP was calculated to be 2.75 [8].
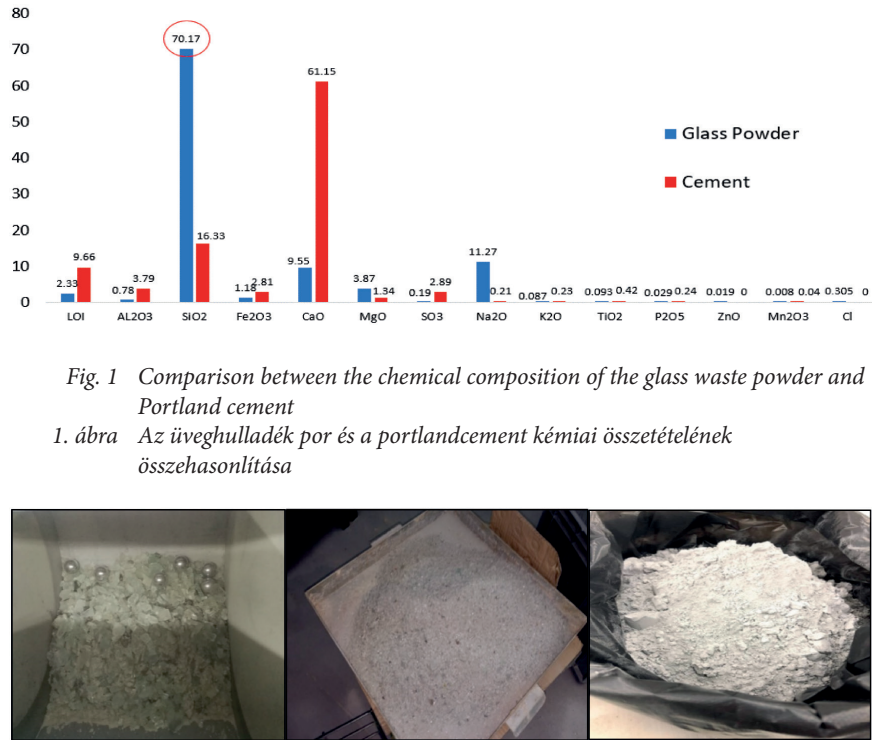

Fig. 2 Glass particles reduced from $30 \mathrm{~mm}$ to less than $75 \mu \mathrm{m}$

2. ábra Üveg részecskék porítása $30 \mathrm{~mm}$-es méretröl kevesebb mint 75 um-re

\subsection{Aggregates}

The used fine aggregates (sand) have a fineness modulus of 2.89 , specific gravity of 2.77 , and water absorption of $3.09 \%$. While the coarse aggregates used have a specific gravity and absorption of 2.46 and 2.41 respectively [8].

\section{Experimental results and discussion}

\subsection{Fresh concrete properties}

The partial replacement of cement with glass powder showed no clear effect on the results of the slump test in both, $25 \mathrm{MPa}$ and $32 \mathrm{MPa}$ concrete mixes. The slump results were very close and within the target values $(25 \mathrm{~mm}-75 \mathrm{~mm})$. The $20 \%$ GWP in $25 \mathrm{MPa}$ concrete mix, resulted in the highest level of slump (75 $\mathrm{mm}$ ), showing an advantage of improving the workability when partially replacing cement with waste glass powder. This partial replacement was however not efficient for the compressive strength (Fig. 3). On the other hand, the results represented in Fig. 4 show that the GWP at $10 \%$ and $15 \%$ resulted in the highest slump in the concrete mix of $32 \mathrm{MPa}(75 \mathrm{~mm})$.
Similarly, the results of the air content test showed no clear effect of the glass powder on the air content in fresh concrete for both concrete grades, as the obtained results were close to the calculated air content for non-air entrained concrete, and within the percentage of air calculated for the control mixes see Fig. 3 and Fig. 4.

The results of the flow table test showed an increase in the flow percentage when the percentage of glass waste powder increase in the $25 \mathrm{MPa}$ concrete mix (Fig. 3), while as shown in Fig. 4, no clear effect was recorded for $32 \mathrm{MPa}$ concrete mix.

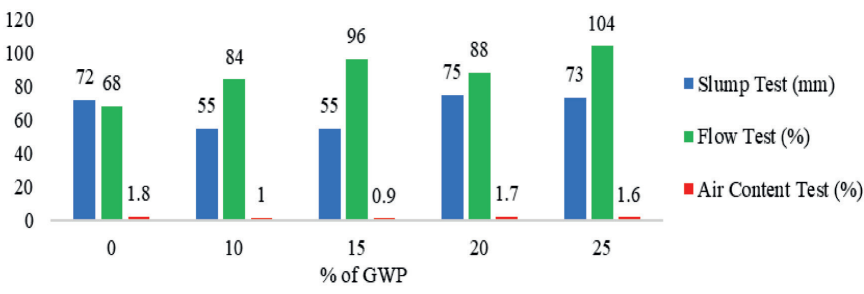

Fig. 3 Results of slump, flow table and air content tests (25MPa Concrete Mix)

3. ábra Roskadás-, terülés- és légtartalom vizsgálat eredményei (25 MPa beton keverék)

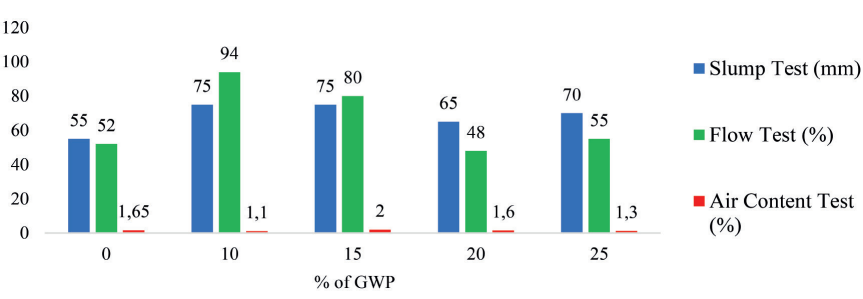

Fig.4 Results of slump, flow table and air content tests (32MPa Concrete Mix) 4. ábra Roskadás-, terülés-és légtartalom vizsgálat eredményei (32 MPa beton keverék)

\subsection{Hardened concrete properties}

For the $25 \mathrm{MPa}$ concrete mix, the results show that the compressive strength of the concrete cylinders at 7, 14 and 28 days decrease with the increase of the \% of GWP. However, for a replacement ratio of $10 \%$, an average compressive strength of $25.6 \mathrm{MPa}$ was achieved, exceeding by that the designed compressive strength at 28 days (Fig. 5). For the $32 \mathrm{MPa}$ concrete grade, the results showed similar trends, except that a higher compressive strength was observed with a replacement ratio of $15 \%$ compared to $10 \%$.Therefore, the use of $15 \%$ GWP as a replacement of cement represent the optimal replacement ratio without affecting the compressive strength of the design mix at the age of 28 days (Fig. 6).

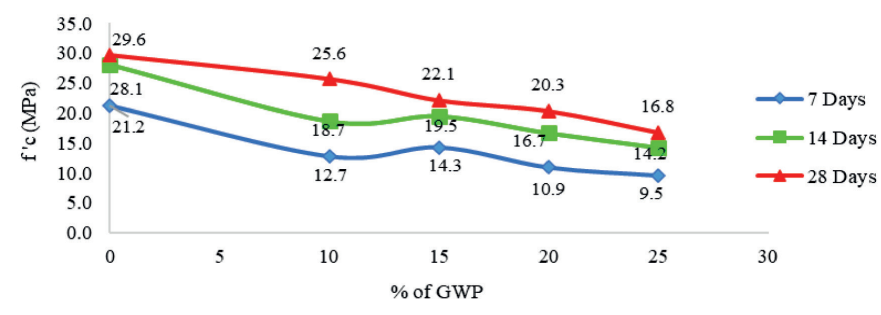

Fig. 5 Evolution of the compressive strength of $25 \mathrm{MPa}$ concrete mix for 7, 14 and 28 days 5. ábra $25 \mathrm{MPa-os} \mathrm{betonkeverék} \mathrm{nyomószilárdságának} \mathrm{alakulása} \mathrm{7,} 14$ és 28 napos korban

Concerning the tensile strength test, the $10 \%$ replacement of cement by GWP in $25 \mathrm{MPa}$ concrete mix increased the tensile strength of the control mix by $0.4 \mathrm{MPa}$ (from $2.4 \mathrm{MPa}$ to $2.8 \mathrm{MPa}$ ). In contrary, the tensile strength test of $32 \mathrm{MPa}$ concrete mix, showed no values above $3 \mathrm{MPa}$ (the tensile strength of the control mix), where the results obtained showed a decrease in the tensile strength when the percentage of replacement of cement by GWP increased (see Fig. 7). 


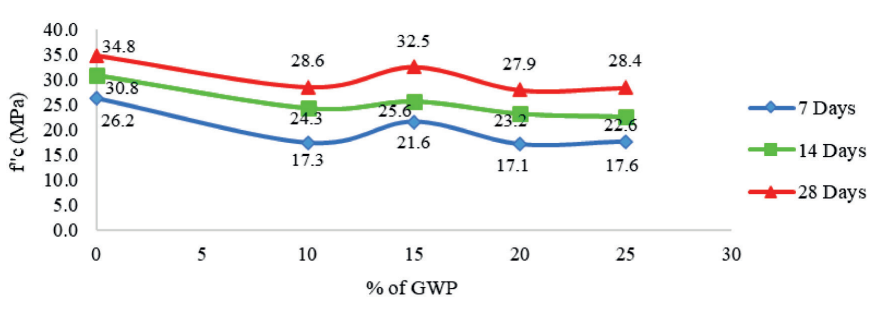

Fig. 6 Evolution of the compressive strength of $32 \mathrm{MPa}$ concrete mix for 7, 14 and 28 days 6. ábra $32 \mathrm{MPa}$-os betonkeverék nyomószilárdságának alakulása 7, 14 és 28 napos korban

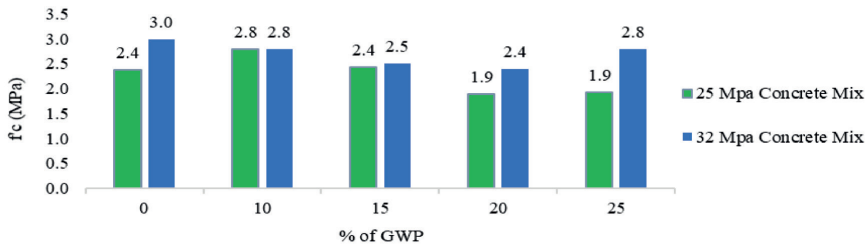

Fig. 7 Results of the tensile strength test of 25 and 32 MPa concrete mixes

7. ábra A 25 és $32 \mathrm{MPa-os} \mathrm{beton} \mathrm{keverékek} \mathrm{húzószilárdság} \mathrm{vizsgálatának} \mathrm{eredményei}$

In terms of durability, the water absorption of the $25 \mathrm{MPa}$ concrete mix with $10 \%$ GWP increased by $17.8 \%$ compared to the control mix. Consequently, construction in cold regions are not encouraged for such concrete use. On the contrary, for the $32 \mathrm{MPa}$ concrete mixes, the water absorption increased when GWP content increased; the concrete mix with 15\% GWP has lowered the water absorption of the control mix (32 MPa) from $2.69 \%$ to $2.64 \%$, whereas $10 \%$ GWP increased this percentage to $3.18 \%$ (Fig. 8).

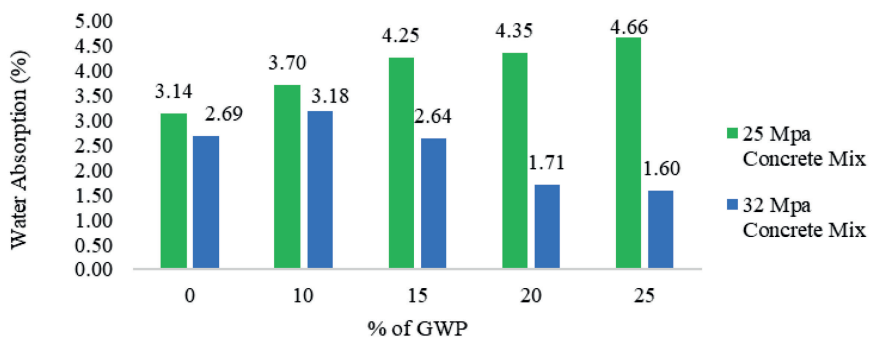

Fig. 8 Results of water absorption test of 25 and $32 \mathrm{MPa}$ concrete mixes 8. ábra A 25 és $32 \mathrm{MPa}$-os beton keverékek vízfelvétel vizsgálatának eredményei

\section{Conclusions and outlook}

In conclusion, this research had revealed that reusing $10 \%$ and $15 \%$ of Glass Waste Powder in $25 \mathrm{MPa}$ and $32 \mathrm{MPa}$ concrete grades respectively has no clear effect on the air content in fresh concrete, but provides a very good workability, as the given slump values were within the target range that was $25 \mathrm{~mm}-75 \mathrm{~mm}$ in both concrete mixes. Concerning the flow table test, the flow percentage increased from $68 \%$ to $84 \%$ and from $52 \%$ to $80 \%$ in $25 \mathrm{MPa}$ and $32 \mathrm{MPa}$ concrete grades respectively.

In term of strength, the results showed that the concrete with Glass Waste Powder averagely has lower compressive strength compared to the control mix at 7, 14 and 28 days in both concrete grades. However, the $10 \%$ and $15 \%$ of Glass Waste Powder that replaced the cement in $25 \mathrm{MPa}$ and $32 \mathrm{MPa}$ concrete mixes respectively, exceeded the target compressive strength of $25 \mathrm{MPa}$ by $2.4 \%$ and $32 \mathrm{MPa}$ by $1.6 \%$.

Therefore, reusing waste materials such glass in new concrete mixes could be a possible solution to save thousands of tons of waste glass from being dumped yearly at landfills and to minimize the environmental effects of cement production and solid waste crisis that Lebanon is suffering from.
However, to standardize the usage of GWP in concrete, there is a need to additionally conduct microscopic and hydration studies for the qualitative assessment and quantitative analysis of hydration and pore fillers according to the physical properties and the chemical compositions of waste glass powder.

\section{Acknowledgments}

The first author would like to express his sincere thanks to the Department of Civil and Environmental Engineering at City University for funding this research.

In addition, the authors acknowledge Al-Sabeh Laboratories who conducted the chemical analysis of the glass powder using the Energy Dispersive X- Ray Fluorescence Spectrometer (ARL-9800 XP).

Furthermore, the first author thanks the head of maintenance department of City University, Eng. Wassim Tarraf, and his team who have facilitated the laboratory experimentation.

\section{References}

[1] Initiative, G. T. (2014): Country Report on the Solid Waste Management in Lebanon. Deutsche Gesellschaft für Internationale Zusammenarbeit (GIZ) GmbH. Retrieved from www.moe.gov.lb

[2] Ecocentra (2016): The cement import "ban" and pollution. ecocentra word press. Retrieved 7 4, 2016, from https://www.google.com/ url?sa=t\&source=web\&rct=j\&url=https://ecocentra.wordpress.com/2016/08/04/ the-cement-import-ban-and-pollution/amp/\&ved=2ahUKEwjNi_ a6tYntAhW8TxUIHZt-A3QQFjAAegQIBBAB\&usg=AOvVaw30o_ xEkklmROPN13E7wCP7\&ampcf $=1$

[3] Aseel B. AL-Zubaid a, K. M. (2017): Study The Effect of Recycled Glass on The Mechanical Properties of Green Concrete. International Conference on Technologies and Materials for Renewable Energy, Environment and Sustainability. Beirut. https://doi.org/10.1016/j.egypro.2017.07.095

[4] G. M. Sadiqul Islam, M. H. (2016): Waste glass powder as partial replacement of cement for sustainable concrete practice. International Journal of Sustainable Built Environment, 37-41. https://doi.org/10.1016/j.ijsbe.2016.10.005

[5] Hongjian Du, K. H. (2014): Waste Glass Powder as Cement Replacement in Concrete. Advanced Concrete Technology, 12. https://doi.org/10.3151/jact.12.468

[6] Kara, P. (2015): Performance of lamp glass waste powder (LGWP) as supplementary cementitious material (SCM) - viscosity and electrical conductivity. Építőanyag - Journal of Silicate Based and Composite Materials, 67(1), 12-18. http://dx.doi.org/10.14382/epitoanyag-jsbcm.2015.3

[7] Kara, P. - Borosnyói, A. - Fenyvesi, O. (2014): Performance of waste glass powder (WGP) supplementary cementitious material (SCM) - Drying shrinkage and early age shrinkage cracking. Építöanyag - Journal of Silicate Based and Composite Materials, 66(1), 18-22. http://dx.doi.org/10.14382/epitoanyag-jsbcm.2014.4

[8] Steven H. Kosmatka, B. K. (2002): Design and Control of Concrete Mixtures Fourteenth Edition (FOURTEENTH EDITION ed.). United States of America. Retrieved from https://www.google.com/ url? sa =t\&source=web\&rct=j\&url=https://www.amazon.com/DesignControl-Concrete-Mixtures-Kosmatka/dp

[9] ASTM, C. (2003): Standard Test Method for Compressive Strength of Cylindrical Concrete Specimens. Retrieved from www.astm.org

[10] ASTM, C. (2004): Standard Test Method for Splitting Tensile Strength of Cylindrical Concrete Specimens. Retrieved from www.astm.org

[11] ASTM, C. (1997): Standard Test Method for Density, Absorption, and Voids in Hardened Concrete. Retrieved from www.astm.org

Ref.:

Bouty, Antonio - Homsi, Farah: The effects of partially replacing cement by glass waste powder on concrete properties

Építőanyag - Journal of Silicate Based and Composite Materials, Vol. 73, No. 2 (2021), 40-43. p.

https://doi.org/10.14382/epitoanyag-jsbcm.2021.7 